Case Report

\title{
Unnoticed impacted foreign body ear presenting as chronic suppurative otitis media with postaural fistula: a rare case
}

\author{
K. C. Prasad, Sreelekshmi S.*, Abhilasha K., Anjali P. K., Induvarsha G., Harshitha N.
}

Department of ENT, Sri Devaraj Urs Medical College, Kolar, Karnataka, India

Received: 10 November 2019

Revised: 06 January 2020

Accepted: 09 January 2020

\author{
*Correspondence: \\ Dr. Sreelekshmi S., \\ E-mail: drsreesnair@gmail.com
}

Copyright: (c) the author(s), publisher and licensee Medip Academy. This is an open-access article distributed under the terms of the Creative Commons Attribution Non-Commercial License, which permits unrestricted non-commercial use, distribution, and reproduction in any medium, provided the original work is properly cited.

\begin{abstract}
Foreign body ear, especially in the external auditory canal are common in adults and children. Most common age group presenting with foreign body is 2 to 10 years. Most common foreign bodies are seeds insects, paper, chalk pieces etc. Most common complications of foreign body ear are pain, bleeding, foul smelling discharge, otitis externa and irritation of ear. There are chances of external auditory canal laceration, bleeding, infection, perforation of tympanic membrane, dislodgement of foreign body towards inner region during the time of removal. This is a case of unnoticed impacted foreign body presented as chronic suppurative otitis media with postaural fistula, found on table broomstick foreign body which was removed using canaloplasty and further managed with tympanoplasty and cortical mastoidectomy.
\end{abstract}

Keywords: Impacted foreign body ear, Postaural fistula, Chronic suppurative otitis media, Unusual foreign body

\section{INTRODUCTION}

Foreign body ear, especially in the external auditory canal are common in adults and children. Most common age group presenting with foreign body is 2 to 10 years. ${ }^{1}$ Sometimes children don't tell their parents that they have inserted a foreign body out of fear, so it often goes undetected and may be found accidentally. Most common foreign bodies found in emergency Department and ENT OPD are broadly classified into inanimate foreign body, vegetable matter and insects. ${ }^{2}$ Inanimate foreign body includes sponge, eraser, paper, chalk, pencil tip, cotton wool. Vegetable foreign body includes beans, seeds. Insect foreign bodies includes housefly, maggots, fleas, ticks, cockroach.

Most common complications of foreign body ear are pain, bleeding, foul smelling discharge, otitis externa and irritation of ear. There are chances of external auditory canal (EAC) laceration, bleeding, infection, perforation of tympanic membrane, dislodgement of foreign body towards inner region during the time of removal.

A brief about the anatomy of external auditory canal, it is $2.5 \mathrm{~cm}$ long in adults, extending from concha to tympanic membrane, outer $1 / 3^{\text {rd }}$ is cartilaginous and inner $2 / 3^{\text {rd }}$ is bony. ${ }^{3}$ Tympanic membrane is obliquely placed at the medial end of external auditory canal. External auditory canal is S- shaped canal and its tortuosity helps in preventing the tympanic membrane injury. Medially and anteroinferiorly the bony wall dips down to form a recess called anterior recess. Foreign body lodged here are difficult to remove usually.

We had a case of foreign body, the child presented as chronic suppurative otitis media (CSOM) with post aural fistula and later was diagnosed as foreign body ear (broom stick) inserted 5 years ago. 


\section{CASE REPORT}

An 8-year-old boy presented to our ENT OPD with complaints of discharge from left ear and post aural region since 2 weeks. He had associated ear pain and decreased hearing. The ear discharge was foul smelling, minimal in quantity, purulent, not blood stained. He had a discharging fistula at the post aural region. He had on and off similar complaints since 5 years. Child gives a history of incision and drainage done twice in a span of 5 years for postaural abscess. No records available. Child was admitted and started on antibiotics. On examination his vitals were stable, microscopic examination showed purulent discharge in external auditory canal with granulation tissue. Ear toileting was attempted but deferred due to poor co-operation of the child, external auditory canal was narrow and occluded by granulation tissue, so tympanic membrane was not visualized. Rinne's test showing bone conduction more than air conduction in left ear and weber lateralised to left. Pure tone audiometry was done showing a hearing loss of 15 $\mathrm{dB}$ in right ear and left ear $42 \mathrm{~dB}$. CT scan showing erosion of the floor of the external auditory canal and soft tissue attenuation lesions noted in the left mastoid and middle ear cavity, with sclerotic mastoid air cells, suggesting otomastoiditis.

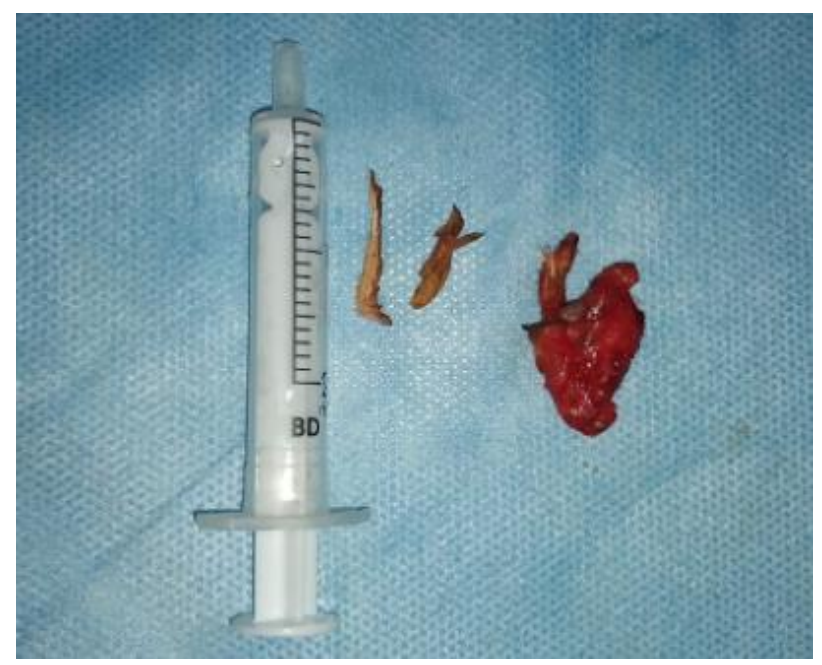

Figure 1: Broomstick with excised fistula tract.

Patient was diagnosed as cholesteatoma with post aural fistula and was taken for surgery, during the procedure, canal wash was given with normal saline, surprisingly an impacted foreign body (multiple small broomstick pieces) was seen in the external auditory canal which was well stuck. We tried to remove that, but was failed in the first attempt, later canaloplasty was done and it was noted that these broomsticks was inserted deep below the floor of external auditory canal one by one we tried removing the broomsticks, there was a fistula present connecting the floor of external auditory canal to externally in the post aural region. Fistula tract was excised completely. Malleus was necrosed, incus and stapes present, round window reflex present. Cortical mastoidectomy with tympanoplasty and ossiculoplasty was done. Patient was treated with intravenous antibiotics postoperatively. Patient was followed up and was completely cured of disease with graft well taken up.

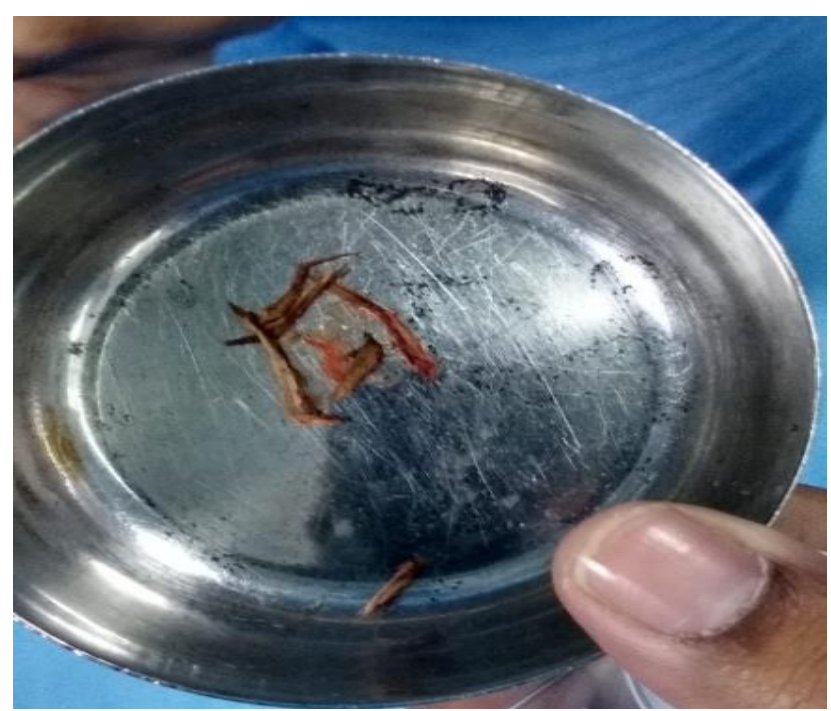

Figure 2: Broomstick.

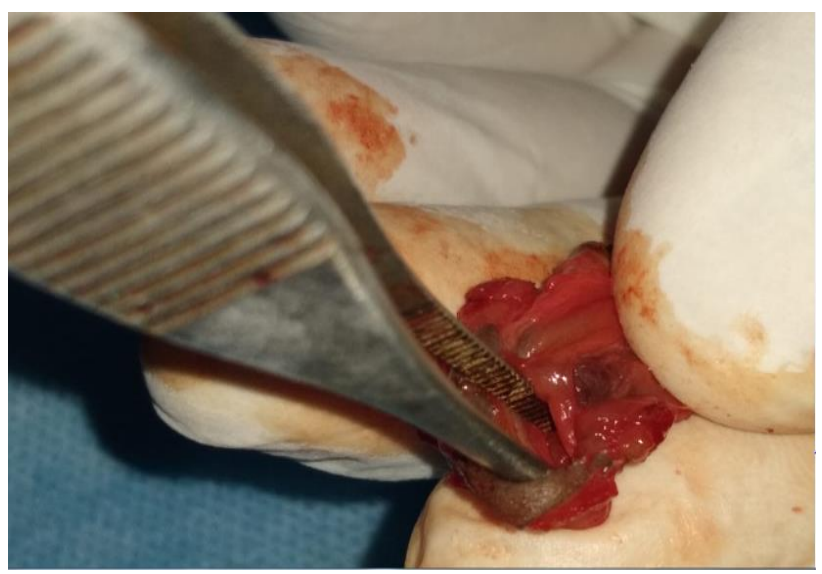

Figure 3: Fistula tract.

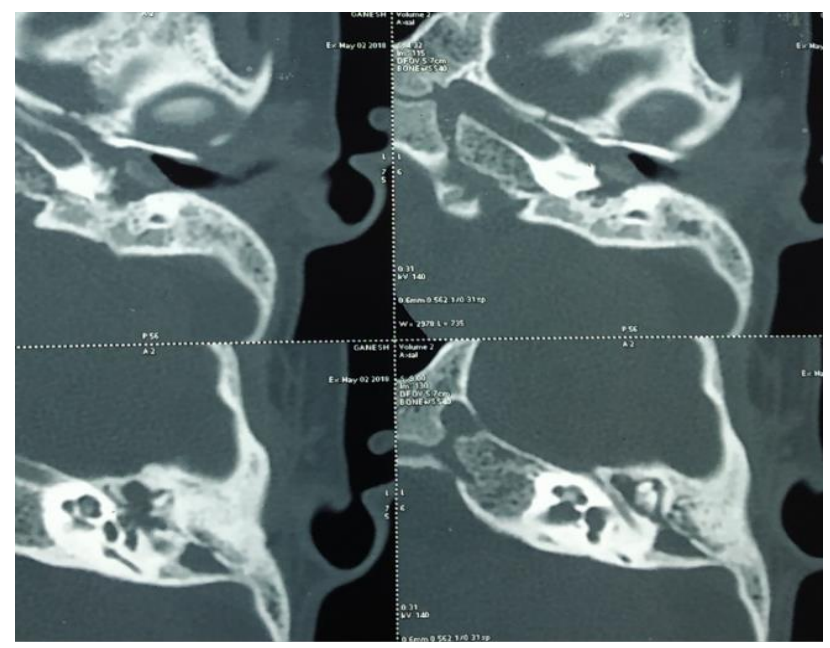

Figure 4: CT showing soft tissue density. 


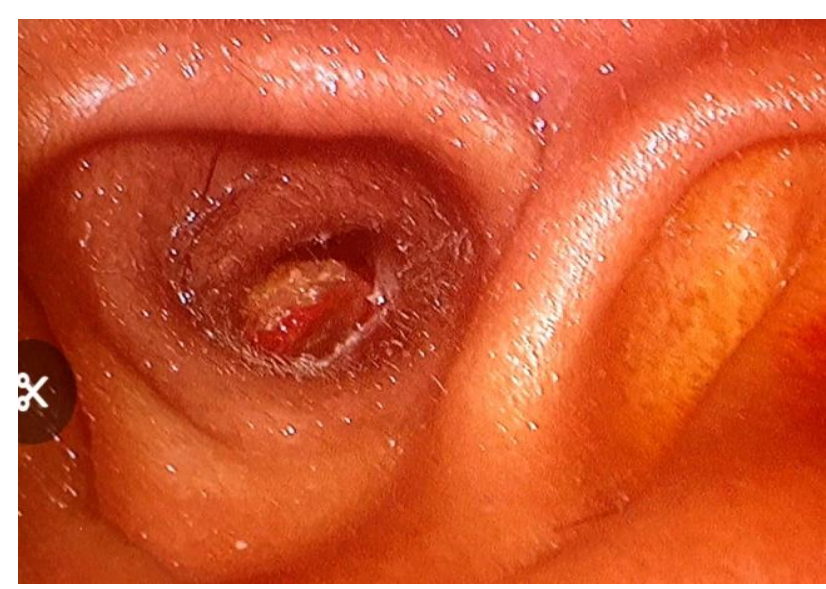

Figure 5: Intraoperative picture of foreign body.

\section{DISCUSSION}

Foreign body of ear are common cases seen in ENT and emergency department. They are most commonly seen in children, but not so uncommon in adults. Usually children present with all kinds of foreign bodies, as they will insert these foreign bodies into the external auditory canal, but adults usually present with insect foreign bodies.

If a patient is presenting with history of repeated infection, the first diagnosis comes to our mind is CSOM. But we should not neglect the possibility of an unforgotten foreign body. A hidden foreign body inserted long back can lead to recurrent infections. A patient presenting with recurrent abscess or infection with poor response to antibiotic therapy with postaural fistula and granulations inside external auditory canal, clinician should have a strong suspicion of a hidden foreign body.

The external auditory canal is narrow at the bony cartilaginous junction so foreign bodies can be easily get impacted at this region. An impacted foreign body is much more difficult to remove on OPD basis, and in children as they may not cooperate for removal of foreign body. Multiple attempts of foreign body removal especially in a non-cooperative patient can result in localized injury, increased pain, bleeding, infection and other serious otologic complications. For a successful removal of foreign body, a cooperative patient, skilled doctor, adequate visualization and proper equipments are needed. ${ }^{4}$

\section{Technique of removing foreign body}

In most of the times foreign body cases present to emergency department on emergency basis because of pain. Some may present late and found out as an incidental finding as they may be asymptomatic or they may present as decreased hearing, otitis media, sense of ear fullness on a later date. Most common foreign bodies taken from children are seeds, beads, pearls, rubber, pencil tip, chalk, paper pieces etc. ${ }^{5-7}$
Removal of foreign body usually depends on the type of foreign body. Most important requirement is proper visualisation of the foreign body, we can remove under direct light or head mirror or microscope, or with endoscope. The use of endoscopes in ear surgeries have increased in recent years.

Various methods by which a foreign body can be removed includes by using a forceps, using jobsons probe, syringing, suction, microscopic removal with special instruments and postaural approach. ${ }^{5}$

Soft and irregular foreign body like a piece of paper, swab or a piece of sponge can be removed by fine crocodile forceps. Seed grains and smooth objects can be removed by syringing or probe, there are chances that seed can swell up if water is used. Smooth and hard objects like pearls steel ball should not be attempted to remove with forceps as they tend to move inwards while grasping with forceps and there are chances of injuring the tympanic membrane. In a perforated tympanic membrane and button battery foreign bodies syringing should be avoided.

In all impacted foreign body and where earlier attempts were made and failed, it is better use an operating microscope and remove the foreign body. If it is impacted in the deep meatus, medial to isthmus or those which have been pushed into middle ear, a postaural approach is used.

In case of living foreign body, no attempts should be made to catch them alive. First, the insect should be killed by applying $4 \%$ xylocaine in the external auditory canal, it kills the insect and provides an anaesthetic field. Once the insect is killed then it's easier to remove with any of the methods described above.

Maggots in the ear are usually seen in the month of August, September, October. Flies may be attracted by foul smelling discharge and they lay eggs which hatch out in the external auditory canal, they present with severe pain with swelling around an ear and blood stained watery discharge. Treatment consists of instilling chloroform water to kill maggots, which can be later removed by forceps. ${ }^{8}$

Uncommon complications of foreign body removal are tympanic membrane perforation, ossicular chain discontinuity, vertigo, facial nerve paralysis, external auditory canal skin damage, surgical complications during post aural approach. ${ }^{6}$

\section{CONCLUSION}

Patients who are presenting with chronic otitis media with postaural fistula, not responding to antiboitics, suspicion should be in mind of an impacted unnoticed foreign body. Here we have described about a rare case of unnoticed impacted pieces of broomstick foreign body 
inserted apparently 5 years ago, presented as CSOM with postaural fistula. Foreign body was removed by canaloplasty and later tympanoplasty with cortical mastoidectomy and ossiculoplasty with fistula tract excision was done to correct the defect caused by this impacted broomstick.

Funding: No funding sources

Conflict of interest: None declared

Ethical approval: Not required

\section{REFERENCES}

1. Piromchai $\mathrm{P}$, Srirompotong $\mathrm{S}$, Lertchanaruengrith $\mathrm{P}$, Mills R. A Child Presenting with a Bullet in the Middle Ear: Case Report. Clin Med Insights Case Rep. 2012;5:1-4.

2. Davies PH, Benger JR. Foreign bodies in the nose and ear: a review of techniques for removal in the emergency department. J Accid Emerg Med. 2000;17:91-4.

3. Shankar T, Swamy DR, Vivechana T. A Rare Foreign Body in the Ear: Removed by Canaloplasty: A Case Report. J Evol Med Dent Sci. 2015;4(67):11762-8.
4. Dance D, Riley M, Ludemann JP. Removal of ear canal foreign bodies in children: What can go wrong and when to refer. BC Med J. 2009;51(1):20-4.

5. Ng TT. Aural foreign body removal: there is no onesize-fits-all method. Open Access Emerg Med. 2018;10:177-82.

6. Marin J, Trainor J. Foreign Body Removal from the External Auditory Canal in a Pediatric Emergency Department. Pediatric Emergency Care. 2006;22(9):630-4.

7. Craig SS, Cheek JA, Seith RW, West A. Removal of ENT foreign bodies in children. Emerg Med Australasia. 2015;27(2):145-7.

8. Al Jabr I. Aural Myiasis, a Rare Cause of Earache. Case Reports Otolaryngol. 2015;219529:1-3.

Cite this article as: Prasad KC, Sreelekshmi S, Abhilasha K, Anjali PK, Induvarsha G, Harshitha N. Unnoticed impacted foreign body ear presenting as chronic suppurative otitis media with postaural fistula: a rare case. Int J Otorhinolaryngol Head Neck Surg 2020;6:585-8. 